\title{
The Life Esidimeni tragedy: A human-rights perspective
}

\author{
B A Ferlito, BPH, BHSc (Honours); A Dhai, PhD, MB ChB, FCOG, LLM, PG Dip (Int Res Ethics) \\ Steve Biko Centre for Bioethics, Faculty of Health Sciences, University of the Witwatersrand, Johannesburg, South Africa
}

Corresponding author: A Dhai (ames.dhai@wits.ac.za)

\begin{abstract}
The International Covenant on Economic, Social and Cultural Rights (ICESCR) affirms that all human beings are entitled to core rights essential to human fulfilment. Although all human rights are important, the ICESCR's guarantee of the right of everyone to the enjoyment of the highest attainable standard of physical and mental health may be the most significant. Having good health is necessary for human wellbeing. Paramount to this is the freedom of individuals to exercise their human rights. As seen with the Life Esidimeni tragedy, people with mental illnesses often find it more difficult than others to achieve the fulfilment of their rights. This article discusses human-rights legal instruments, and focuses on the rights to health, life and dignity in the context of the tragedy. It also examines how the realisation of human rights can have meaningful results for mentally ill people.
\end{abstract}

S Afr J Bioethics Law 2017;10(2):52-54. DOI:10.7196/SAJBL.2017.v10i2.627

The International Covenant on Economic, Social and Cultural Rights (ICESCR) affirms that all human beings are entitled to core rights essential to human fulfilment, such as the rights to work, social security, family life, education and participation in cultural life. ${ }^{[1]}$ Although all human rights and entitlements are important, the ICESCR's guarantee of 'the right of everyone to the enjoyment of the highest attainable standard of physical and mental health' may be the most significant. ${ }^{[1]}$

Individuals and communities at large assign health a special meaning. Having good health is necessary for human wellbeing, as it provides inherent value for comfort, fulfilment and the pursuit of the joys of life. However, good health goes beyond that. ${ }^{[1]}$ Of paramount importance to good health is the freedom of individuals to exercise a wide scope of human rights - civil and political (e.g. personal security and political participation), and social and economic (e.g. education, social security and family life). Health is therefore necessary for wellbeing. When individuals do not have a decent level of health, it is very difficult to achieve the fulfilment of their human rights. ${ }^{[1]}$

People with mental illnesses often find it especially difficult to achieve this, as they face a number of barriers to healthcare, such as inadequate care and treatment, and severe discrimination. ${ }^{[2,3]}$ In many cases, these barriers are motivated by the misconceptions associated with mental illness, and this can impact an individual's ability to exercise his or her human rights..$^{[2,4,5]}$ Therefore, protecting the human rights of mentally ill people can ensure them their core rights essential to human fulfilment. ${ }^{[1,6]}$

This article discusses human-rights legal instruments, and focuses on the rights to health, life and dignity with regard to the Life Esidimeni (LE) tragedy. It takes into consideration existing challenges to the realisation of the rights of the mentally ill, and examines how the true 'progressive' realisation of human rights can have meaningful results for mentally ill people.

\section{International, regional and national human-rights law instruments}

International and regional human-rights instruments are significant in the context of mental health, as 'they are the only source of law that legitimises international scrutiny of mental-health policies and practices within a sovereign country, and also because they provide fundamental protections that cannot be taken away by the ordinary political process. ${ }^{\prime[7]}$ Among these legal instruments is the International Bill of Rights, which consists of the United Nations (UN) Declaration of Human Rights (UDHR, 1948), ${ }^{[8]}$ the ICESCR (1966) ${ }^{[9]}$ and the International Covenant on Civil and Political Rights (1966). ${ }^{[10]}$ Although the UDHR is not, per se, a legally binding instrument, it does establish a fundamental set of human rights that applies to all nations. Other instruments include the Convention on the Rights of Persons with Disabilities (CRPD, 2006), ${ }^{[11]}$ the Convention Against Torture and other Cruel, Inhuman or Degrading Treatment or Punishment (1983) $)^{[12]}$ and the Convention on the Elimination of All Forms of Discrimination Against Women (CEDAW, 1979). ${ }^{[13]}$ Regional human-rights law instruments include the African Charter on Human and People's Rights (1986). ${ }^{[14]}$

Nationally, the Republic of South Africa (SA) has its own set of human-rights laws around the rights of mentally ill persons, which are derived from international and regional law. ${ }^{[15,16]}$ SA, having signed and/or ratified the abovementioned international and regional legal instruments, '[is] obliged to respect, protect and fulfil the rights enshrined in them, ${ }^{[7,17]}$ The Bill of Rights, under section 39(1)(b) of the Constitution of $\mathrm{SA}^{\left[{ }^{[17]}\right.}$ states that the courts and other legal bodies 'must consider international law', and section 231(2) and (4) state that international law, approved by Parliament, binds the republic to that law. SA is therefore legally and morally bound to respect international and regional legal instruments.

Pertinent to the human rights of mentally ill people in SA is the Constitution, ${ }^{[17]}$ the National Health Act No. 61 of 2003 (NHA) ${ }^{[18]}$ and the Mental Healthcare Act No.17 of 2002 (MHCA). ${ }^{[19]}$ The National 
Mental Health Policy Framework and Strategic Plan 2013 - 2020 (MH policy) ${ }^{[20]}$ and the White Paper on the Rights of Persons with Disabilities $^{[21]}$ are also important to the human rights of mentally ill people in SA.

\section{The right to health}

Health is an indispensable human right, needed for the realisation of other human rights, such as life and dignity, and therefore every person 'is entitled to the enjoyment of the highest attainable standard of health conducive to living a life in dignity. ${ }^{[9]}$ The ICESCR provides the most comprehensive article on the right to health. In line with article 12.1 of the ICESCR, states recognise the right of everyone to the enjoyment of the highest attainable standard of physical and mental health. ${ }^{\left[{ }^{[}\right]}$The right to health is also recognised, inter alia, in article 5(iv) of the International Convention on the Elimination of All Forms of Racial Discrimination, ${ }^{[22]}$ and in article 14(b) of the CEDAW. ${ }^{[13]}$ Regionally, the right to health is recognised in the African Charter (article 16). ${ }^{[14]}$ Nationally, the right to health is enshrined in Section 27 of the Bill of Rights: the right to 'healthcare, food, water and social security.' The right to health must be progressively realised by the SA state, within its available resources. ${ }^{[17]}$

The Committee on Economic, Social and Cultural Rights of the ICESCR $^{[23,24]}$ gives a detailed account of 'interrelated and essential elements' regarding what the right to health entails, and these can help improve a country's health system. These are availability, accessibility, acceptability and quality.

Availability refers to a functioning health system. This includes the underlying determinants of health, such as safe drinking water and adequate sanitation facilities, trained medical personnel and essential drugs, ${ }^{[23]}$ as defined by the World Health Organization (WHO)'s Action Programme on Essential Drugs. ${ }^{[25]}$ The programme classifies drugs for the mentally ill as essential. Furthermore, principle 10 of the United Nations' Principles for the Protection of Persons with Mental IIIness and the Improvement of Mental Healthcare (MI principles) ${ }^{[26]}$ affirms that 'medication shall meet the best health needs of the patient'. Principle 14(1)(d) states that patients should have access to 'adequate, regular and comprehensive treatment, including supplies of medication'. An investigation into the LE tragedy conducted by the health ombudsman of $\mathrm{SA}^{[27]}$ revealed that patients died of severe dehydration, and that they did not have access to adequate drinking water and sanitation facilities. In addition, the personnel at the non-governmental organisations (NGOs) that they were placed in were not trained medical personnel. Also, many of the patients did not receive their medication most patients were discharged from Life Esidimeni without their discharge summaries. ${ }^{[27]}$ The failure to discharge patients with their summaries may be because patients were hurriedly removed from the facilities of LE. These actions by the Gauteng Department of Health (GDoH) led to some patients becoming wasted and some dying prematurely. ${ }^{[27]}$ The lack of availability of a functioning healthcare system and access to essential drugs unambiguously violated these patients' right to health.

Accessibility refers to healthcare facilities, goods and services that are accessible to everyone without discrimination on any grounds. The Office of the United Nations High Commissioner for Human Rights states that 'non-discrimination is a key principle in human rights and it is crucial to the enjoyment of the right to the highest attainable standard of health' ${ }^{\text {[28] }}$ However, in the context of the LE tragedy, this was clearly not the case. It was discovered that the 'plan' to reduce the number of patients housed at LE by $20 \%$ was carried out in an inconsistent manner and to cut costs. ${ }^{[27]}$ The ombudsman's investigation found it suspicious that NGOs were expected to take care of mentally ill patients at the cost of ZAR112 per day, as compared with the ZAR320 per day that LE charged. ${ }^{[27]}$ Could it be that these patients were discriminated against because they had a mental illness? The investigation found that the cost reduction rationale represented serious forms of neglect and denial (discrimination) of care to the patients. ${ }^{[27]}$ The GDoH is deployed by the state, and therefore a violation of Section 9(3) of the Constitution occurred: 'the state may not unfairly discriminate directly or indirectly against anyone on one or more grounds, including ... disability. ${ }^{\text {[17] }}$ Article 25 of the CRPD states that 'persons with disabilities have the right to the enjoyment of the highest attainable standard of health without discrimination on the basis of disability. ${ }^{[11]}$

Acceptability refers to healthcare facilities and services that are respectful of medical ethics, and that improve the health status of patients. ${ }^{[23]}$ There was a total disregard of the values of medical ethics. The patients' removal from the LE facilities to ill-resourced NGOs resulted in morbidity and mortality, instead of an improvement in health status. The GDoH took no steps to ensure the acceptability of the NGOs.

In terms of good quality of healthcare, principle 1(1) of the MI principles affirms that 'all persons have the right to the best available mental healthcare, [26] while article 25(a) of the CRPD affirms that persons with mental illness should be provided with quality mental healthcare. ${ }^{[1]}$ Additionally, section 66(b) of the MHCA ${ }^{[19]}$ states that quality treatment must be provided for mentally ill persons. The Act unfortunately does not define what this quality treatment entails. The investigation, however, did find that patients received 'substandard care'. The investigation also found that several NGOs were in fact residential properties (not healthcare facilities) and did not have suitable infrastructure to house these patients. ${ }^{[27]}$ The NHA defines a health facility as'a building or place ... designed to provide inpatient or outpatient treatment, ${ }_{1}^{\prime[18]}$ while the MHCA uses this same definition. Therefore, the housing of patients at these residential NGOs was in direct violation of both Acts. In addition, section 24(b) of the Constitution states that 'everyone has the right to an environment that is not harmful to their health or wellbeing.[17] The ombudsman's investigation found that on inspection of the NGOs, the environment was not conducive to patients' mental health. Many of the NGOs did not have adequate security arrangements, which put patients at an increased risk of danger. ${ }^{[27]}$ Also, many of the NGOs lacked the capacity, skills and competence to look after mentally ill patients, which was in direct violation of section 6(1)(a) of the MHCA, ${ }^{[19]}$ which affirms that mental healthcare must be provided at health establishments within its scope of practice. NGOs provided care outside of this definition.

\section{The right to dignity}

The notion of dignity is often interlinked with that of social justice. Social justice is generally equated with the notion of fairness in society, including for the most vulnerable. The dignity of each human being in society can only be achieved when every member of society is treated as equal. ${ }^{[2,6]}$ 
Article 1 of the UDHR, ${ }^{[8]}$ article 3 of the CRPD, ${ }^{[1]]}$ article 5 of the African Charter ${ }^{[14]}$ and section 10 of the Constitution ${ }^{[17]}$ affirm that everyone has a right to dignity. The African Charter explicitly states that 'every individual shall have the right to the respect of the dignity inherent in a human being, and to the recognition of his legal status. All forms of exploitation and degradation of man, particularly ... cruel, inhuman or degrading punishment and treatment shall be prohibited.'[14] Regrettably, some of the patients were forced to sleep on floors, went hungry and suffered from dehydration, depriving them of their dignity ${ }^{[27]}$ and subjecting them to cruel, inhumane and degrading treatment, which was also in violation of the Convention against Torture. ${ }^{[12]}$ Once more, the transfer of mentally ill patients is regulated by section 72 of the MHCA. ${ }^{[19]}$ This means that patients should be transferred in a suitable and dignified manner. However, the investigation found that this was not the case. The CRPD ${ }^{[1]}$ highlights dignity of persons with mental disabilities in several articles. Article 19 underpins the right of people with mental disabilities to live in society, equal to others. This aims to ensure the development and growth of people with mental disabilities to achieve self-worth and dignity. Additionally, the care of people with mental disabilities is highlighted in article 25 , which requires 'health professionals to provide care of the same quality to persons with disabilities as to others ... raising awareness of the human rights, dignity, autonomy and needs of persons with disabilities through training and the promulgation of ethical standards.' ${ }^{[1]}$ The GDoH, however, by unashamedly failing to adhere to ethical norms and standards, abominably violated the right to dignity of these patients.

\section{The right to life}

Article 3 of the UDHR, ${ }^{[8]}$ article 10 of the ICESCR, ${ }^{[9]}$ article 10 of the $\mathrm{CRPD}^{[11]}$ article 4 of the African Charter ${ }^{[14]}$ and section 11 of the Constitution ${ }^{[17]}$ affirm that every human being has a right to life. Despite this, the ombudsman's investigation concluded that patients died under unlawful circumstances, and that their right to life was violated. ${ }^{[27]}$ While the right to health is dependent on the realisation of other rights, a compelling argument can be made for the right to life being dependent on the rights to health and dignity. To illustrate this, article 10 of the CRPD, ${ }^{[11]}$ on which SA based its White Paper, establishes that 'state parties reaffirm that every human being has the inherent right to life and shall take all necessary measures to ensure its effective enjoyment by persons with disabilities on an equal basis with others.' The key notion in this affirmation is 'shall take all necessary measures', and that includes the realisation of the rights to health and dignity. The GDoH did not take all the necessary measures to fulfil the right to life of these patients. Perhaps, if it had done so, their unlawful deaths could have been averted.

\section{The legal and moral duties of the GDoH}

SA and its duly appointed subsidiary, the $\mathrm{GDoH}$, are bound by international and regional law under the Constitution (s 231(2) and (4)). The GDoH is required by law to follow and apply any international and regional law relevant to SA. According to section $3(2)$ of the $\mathrm{NHA}_{1}{ }^{[18]}$ 'every provincial department ... must establish such health services as are required in terms of this act, and all health establishments and healthcare providers in the public sector must equitably provide health services.' In addition, section 25(1) of the act states that 'the relevant member of the executive council must ensure the implementation of national health policy, norms and standards in his or her province,' i.e., in this case, the MH policy. The GDoH and the former member of the executive council (MEC) had a legal and moral duty to ensure that international, regional and national laws, polices and guidelines were being adhered to. Although the NGOs played a huge role in the deaths and ill treatment of these patients, they were contracted by the GDoH, who were fully aware that the NGOs were not capable of caring for mentally ill patients, professionally, medically or structurally. The GDoH was also advised by various stakeholders not to transfer the patients. ${ }^{[27]}$ Therefore, if the department could not provide the requisite standard of care for their patients, they had a legal duty to contract suitably qualified healthcare providers, as stipulated in the NHA. ${ }^{[18]}$ Furthermore, the MHCA, ${ }^{[19]}$ in its preamble, recognises that 'there is a need to promote the provision of mental healthcare services in a manner which promotes the maximum mental wellbeing of users of mental healthcare services and communities in which they reside.' Therefore, considering all laws, policies and guidelines cited herein, it can reasonably be concluded that the GDoH fell foul of their legal and moral obligations and duties, by negligently consigning the care of their patients to the hands of incompetent people and/or facilities that lacked the necessary capacity.

\section{Conclusion}

SA has done considerably well by signing international law and enacting legislation aimed at realising the human rights of mentally ill people. While this is laudable, the Life Esidimeni tragedy is, however, an indication of how far SA is from realising the human rights of the mentally ill. Protecting the rights of mentally ill people is important, as they safeguard patients from neglect and abuse. However, the implementation of laws to defend these rights remains an important factor if we are to avoid tragedies like that which occurred in the Life Esidimeni situation. It is high time that our country moved away from protections being just a paper exercise. Our state has a responsibility to be accountable to all its citizens - even those who are mentally ill.

1. Ruger JP. Health and social justice. Lancet 2004;364(9439):1075-1080. https://doi. org/10.1016/S0140-6736(04)17064-5

2. Maiese M. Human Rights Violations. Beyond Intractability. 2003. http://www. beyondintractability.org/essay/human-rights-violations (accessed 1 September 2017).

3. Mfoafo-M'Carthy $M$, Huls $S$. Human rights violations and mental illness: Implications for engagement and adherence. SAGE Open 2014;4(1):1-18. https:// doi.org/2158244014526209

4. Corrigan P. How stigma interferes with mental health care. Am Psychol 2004;59(7):614-625. https://doi.org/625:10.1037/0003-066X.59.7.614

5. Sorsdahl KR, Stein DJ. Knowledge of and stigma associated with mental disorders in a South African community sample. J Nerv Ment Dis 2010;198(10):742-747. https://doi.org/10.1097/NMD.0b013e3181f4b2d7

6. Ebert R, Oduor RM. The concept of human dignity in German and Kenyan constitutional law. Thought Prac 2012;4(1):43-73.

7. Ventura CA. International Law, Mental Health, and Human Rights. Notre Dame: The Center for Civil \& Human Rights, 2014. https://humanrights.nd.edu/ assets/134859/venturamentalhealth.pdf (accessed 1 September 2017).

8. United Nations General Assembly. Universal Declaration of Human Rights. Paris: UN, 1948. 217 A (III). http://www.un.org/en/udhrbook/pdf/udhr_booklet_en_ web.pdf (accessed 17 July 2017).

9. United Nations General Assembly. International Covenant on Economic, Social and Cultural Rights. United Nations, Treaty Series, vol. 993. New York: UN, 1966. http:// www.ohchr.org/EN/Professionallnterest/Pages/CESCR.aspx (accessed 17 July 2017).

10. United Nations General Assembly. International Covenant on Civil and Political Rights. United Nations, Treaty Series, vol. 999, p. 171. New York: UN, 1966. https:// treaties.un.org/doc/publication/unts/volume\%20999/volume-999-i-14668english.pdf (accessed 1 September 2017). 
11. United Nations Division for Social Policy and Development. Convention on the Rights of Persons with Disabilities. UN, 2006. https://www.un.org/development/ desa/disabilities/convention-on-the-rights-of-persons-with-disabilities.html (accessed 17 July 2017).

12. United Nations General Assembly. Convention Against Torture and Other Cruel, Inhuman or Degrading Treatment or Punishment, United Nations Treaty Series, vol. 1465, p. 85. New York: UN, 1984. https://treaties.un.org/doc/Publication/UNTS/ Volume\%201465/volume-1465-I-24841-English.pdf (accessed 1 September 2017).

13. United Nations General Assembly. Convention on the Elimination of All Forms of Discrimination Against Women. United Nations, Treaty Series, vol. 1249, p. 13. New York: UN, 1979. http://www.un.org/womenwatch/daw/cedaw/text/econvention. htm (accessed 1 September 2017).

14. Organization of African Unity. African Charter on Human and Peoples' Rights (Banjul Charter). 1986. CAB/LEG/67/3 rev. 5, 21 I.L.M. 58. OAU, 1982. http://www. achpr.org/files/instruments/achpr/banjul charter.pdf (accessed 17 July 2017).

15. Dugard J. International law: A South African Perspective. Kenwyn: Juta and Co., 1994.

16. Reisman WM. Sovereignty and human rights in contemporary international law. Amer J Intl Law 1990;84(4):866-876.

17. South Africa. The Constitution of the Republic of South Africa Act No. 108 of 1996. http://www.gov.za/sites/www.gov.za/files/Act108of1996s.pdf (accessed 17 July 2017).

18. South Africa. 2003. National Health Act No.61 of 2003. http://www.gov.za/sites/ www.gov.za/files/38486_r10367_gon109.pdf (accessed 17 July 2017).

19. South Africa. 2002. Mental Healthcare Act No.17 of 2002. http://www.gov.za/sites/ www.gov.za/files/a17-02.pdf (accessed 17 July 2017).

20. South Africa. National Department of Health. National Mental Health Policy Framework and Strategic Plan 2013 - 2020. https://www.health-e.org.za/wpcontent/uploads/2014/10/National-Mental-Health-Policy-Framework-andStrategic-Plan-2013-2020.pdf (accessed 9 August 2017).

21. South Africa. Department of Social Development White Paper on the Rights of Persons with Disabilities. 2015. http://www.gov.za/sites/www.gov.za/files/39792 gon230.pdf (accessed 1 September 2017).
22. United Nations General Assembly. International Convention on the Elimination of All Forms of Racial Discrimination United Nations, Treaty Series, vol. 660, p. 195. UN, 1965. http://www.ohchr.org/Documents/Professionallnterest/cerd.pdf (accessed 1 September 2017).

23. United Nations Committee on Economic, Social and Cultural Rights. Twenty second Session on The Right to the Highest Attainable Standard of Health (General Comment 14). UN, 2000. http://www.minoritycentre.org/sites/default/files/cescr gen_comm_14_health.pdf (accessed 1 September 2017).

24. Robertson RE. Measuring state compliance with the obligation to devote the maximum available resources to realizing economic, social, and cultural rights. Hum Rts Q 1994;16(4):693-714. https://doi.org/10.2307/762565

25. World Health Organization. Action Programme on Essential Drugs. Geneva: WHO 1992. http://apps.who.int/medicinedocs/pdf/s2237e/s2237e.pdf (accessed 1 September 2017).

26. United Nations General Assembly. The Principles for the Protection of Persons with Mental Illness, resolution 46/119 of 17 December 1991. UN, 1991. http://www.who. int/mental_health/policy/en/UN_Resolution_on_protection_of_persons_with_ mental_illness.pdf (accessed 1 September 2017).

27. Makgoba MW. The Life Esidimeni disaster: The Makgoba report. PoliticsWeb, 1 February 2017. http://www.politicsweb.co.za/documents/the-life-esidimenidisaster-the-makgoba-report (accessed 10 July 2017).

28. United Nations Office of the High Commissioner for Human Rights. Fact Sheet No. 31, The Right to Health 2008 No. 31. Geneva: UNOHCHR, 2008. http://www.ohchr. org/Documents/Publications/Factsheet31.pdf (accessed 17 July 2017).

Accepted 23 November 2017 